\author{
Monika Grygiel \\ Katolicki Uniwersytet Lubelski (Lublin, Polska)
}

\title{
METAFIZYKA PAMIECI WE WSPOMNIENIOWEJ PROZIE VLADIMIRA NABOKOVA
}

Problematyka metafizyczna prozy Vladimira Nabokova obejmuje szereg zagadnień powiązanych przez autora ze sferą irracjonalności, wieczności, tajemnicą życia i śmierci człowieka ${ }^{1}$. We wszystkich swych tekstach Nabokov bezpośrednio, a przeważnie pośrednio porusza tematy, które frapowały jego samego, problemy, które także należą do metafizycznych dociekań filozofów, myślicieli czy pisarzy. Uznany za człowieka niepośledniego, wybitnego twórcę jeszcze za życia, Nabokov osiągnął autorytatywną pozycję, o jakiej zresztą marzył i do jakiej zawsze predystynował. W swoich dążeniach do wypracowania niezależnej pozycji w świecie artystycznym, pisarz nie wahał się przed wykorzystaniem nowatorskich artystycznie eksperymentów, konsekwentnie sięgając także po kanoniczne formy, zasady i wartości. Wirtuozerię i racjonalizm formy artystycznej u Nabokova przenika metafizyczna teść, która buduje niepowtarzalny i atrakcyjny świat fascynujący kolejne pokolenia badaczy i czytelników pisarza. Dwuświatowość (биспациальность) czyli przenikanie się racjonalnego z irracjonalnym, wprowadzenie problematyki metafizycznej w prawdopodobną treść, ujętą w oryginalną stylistykę i patronat wszechobecnego autora, stanowią niezaprzeczalne atuty prozy Nabokova. A metafizycznych aspektów ukrytych pod fasadą słów nie sposób ignorować tym bardziej, iż przesycony jest nimi cały dorobek pisarza, włącznie z jego autobiografią. Stałe metafizyczne dociekania Nabokova obejmują sferę zagadnień związanych z pamięcią, czasowością i wiecznością.

Nieocenione znaczenie pamięci jako czynnika warunkującego poznanie i rozumienie rzeczywistości było waloryzowane już w starożytności, a sprzy-

${ }^{1}$ Aspekty metafizyczne w twórczości V. Nabokova omawiają m. in. badacze: В. Е. Александров, Набоков и потусторонность: метафизика, этика, эстетика, Санкт-Петербург 1999; L. Engelking, Chwyt metafizyczny. Vladimir Nabokov - estetyka z sankcją wyższej rzeczywistości, Łódź 2011; Б. Аверин, Дар Мнемозины. Романы Набокова в контексте русской автобиографической традиции, Санкт-Петербург 2003. 
jała temu osobowa forma wspomnienia formułująca indywidualną świadomość ${ }^{2}$. Wspomnienia, memuary i ego literatura, szczególnie preferowana przez artystów od czasu romantyzmu (por. Fabianowski 2001: 95) 3 po współczesność (por.: Czermińska 2009; Czermińska 1987; Lubas-Bartoszyńska 1993) oferowała twórcom możliwość indywidualnego przedstawienia świata i swojego miejsca w nim, swojej wizji rzeczywistości. Autobiografia miała szczególnie poznawczą wartość dzięki antropologicznej refleksji (Gusdorf 2009: 264), która pojawia się w wyniku zagłębiania się autora $\mathrm{w}$,proces samopoznania i autoidentyfikacji” (Kasperski 2001: 15-22). Po autobiografie i memuary sięgali chętnie twórcy pierwszej fali emigracji rosyjskiej ${ }^{4}$, podtrzymując w ten sposób mentalną łączność z przedrewolucyjną Rosją i jednocześnie pielęgnując tożsamość narodową i kulturową Rosjan poza granicami ojczyzny.

Podobne cele przyświecały Vladimirowi Nabokovowi, kiedy postanowił opisać swe dzieciństwo i młodość w ojczyźnie, studia w angielskim Cambridge, okresy berliński i paryski, do momentu opuszczenia Europy i przejazdu do Stanów Zjednoczonych. Autobiografia Nabokova miała zaspokoić ciekawość żądnych informacji o autorze czytelników, którzy nie znali faktów z jego życia, dostrzegali natomiast autobiograficzne motywy jego twórczości. Borys Awierin słusznie przekonuje, że Nabokov stworzył nowy typ twórczości autobiograficznej, ponieważ w tych kategoriach należy dorobek pisarza analizować jako jedną całość i uznać autobiografię jedynie za kolejny dopełniający go element (Аверин 2003: 13-14). Badacz bowiem podkreśla znaczącą rolę fikcji literackiej, która w autobiografii Nabokova pozostaje w korelacji z pozostałymi jego powieściami i tworzy spójną strukturę artystyczną. W naszym przekonaniu o specyfice nabokovowskiego autobiografizmu decyduje także fakt biograficznej konceptualizacji, poprzez którą pisarz starał się wyjaśnić filozofię własnego postrzegania i oceny rzeczywistości, nazwać kategorie kluczowe w życiowej i pisarskiej hierarchii. Zasadniczo Nabokov skupia się więc nie na czynnikach zewnętrznych, kształtujących jego świadomość i wrażliwość, lecz podkreśla przede wszystkim indywidualizm i subiektywizm w formowaniu pisarskiego światopoglądu, czyli preferuje cechy uznane za kluczowe dla jego literaturys.

${ }^{2}$ W filozofii Arystotelesa, następnie Platona pamięć określana jest jako przyczyna do poznania i rozumienia świata, bowiem decydować miał o tym jej charakter - wieczny i boski. Paul Ricoeur utrzymuje, że świadomość trwania w czasie jest możliwa dzięki pamięci, która także warunkuje opis człowieka jako osoby; por. Yates 1977: 33; Ricoeur 1992: 33.

${ }^{3}$ We współczesnych badaniach literaturoznawczych proponuje się rozróżnienie terminów ,autobiografia” i autobiografizm”, por. szczegółowo na ten temat: Kasperski 2001: 10-14.

${ }^{4}$ O. Demidowa nazywa mnogość i różnorodność twórczości wspomnieniowej emigrantów „pierwszej fali” memuarystycznym boomem («мемуарный бум»), do którego wlicza Tamte brzegi i kolejne wersje autobiografii Nabokova (por. Демидова 2010: 30).

5 O. Fiedotow przekonuje, że w ego literaturze subiektywizm jest metodologiczną konsekwencja opisu samego siebie („самоописание”) poprzez opisanie konkretnego osobistego świata, opartego na światopoglądzie samego autora (por. Федотов 2010: 5-6). 
Jeden z chwytów artystycznych Nabokova polega na ciągłym powracaniu do przeszłości czyli odwoływaniu się do znanych z wcześniejszych jego utworów motywów, szczegółów, komponentów, które ujęte są w przemyślną i uzupełniającą się konstrukcję. Czytanie i analizowanie twórczości Nabokova nie powinno być zatem wyrywkowe, ponieważ kolejne powieści powiązane są ze sobą nie tylko poprzez autora, ale przede wszystkim pozostają w finezyjnej szachowej czy „matrioszkowej” konfiguracji. Współzależność kolejnych nabokovowskich tekstów opiera się na powtarzaniu oraz na zapamiętywaniu przez czytelnika wybranych przez autora elementów składowych jego dzieł, polegających między innymi na częstym wykorzystaniu motywów autobiograficznych. Zapamiętywanie i utrwalanie przyswojonej wiedzy poprzez powtarzanie, to jeden z ulubionych zabiegów artystycznych Nabokova, który tym samym wskazuje, czy podpowiada czytelnikom, jakie idee i wartości były ważne dla niego samego. Nabokov posiadał wspaniałą, drobiazgową, wyćwiczoną od dzieciństwa pamięć, co potwierdzają jego autobiografie i wspomnienia jego przyjaciół. Należy także stwierdzić, iż pamięć należy do jednej z najważniejszych wartości świata przedstawionego w prozie V. Nabokova. Już jego pierwsza powieść Maszeńka opiera się w swej fabularnej formie na wspomnieniu, pamięć zaś jest kryterium weryfikacji rzeczywistości, czynnikiem kształtującym świadomość głównego bohatera. W ten sposób pisarz na początku prozatorskich dokonań określił zadania, jakie przypisuje pamięci, najbardziej indywidualnemu nośnikowi czasu, formującemu osobowość człowieka, jego duszę. Kolejne powieści Nabokova są równie cennym źródłem informacji na temat pisarskiej koncepcji pamięci, czasu przeszłego zamkniętego w teraźniejszości, najwyraźniejszy obraz czasowych wyobrażeń pisarza możemy jednakże odnaleźć w jego dwóch autobiografiach Tamte brzegi, rosyjskiej wersji z 1954 r. i anglojęzycznej Pamięci przemów ukończonej w 1966 r. Druga autobiografia była rozwinięciem i uzupełnieniem pierwszej, w niej zatem można poszukiwać danych na temat nabokovowskiej teorii czasowości, pamięciowych nośników świadomości.

Obydwie wersje autobiografii rozpoczynają się od słów:

Колыбель качается над бездной, и здравый смысл говорит нам, что жизнь - только щель слабого света между двумя вечностями тьмы. Хотя обе они - совершенные близнецы, человек, как правило, с пущим спокойствием вглядывается в бездну преджизненную, чем в ту, к которой летит (со скоростью четырех тысяч пятисот ударов в час). (19) ${ }^{6}$

Nabokov odwołuje się do najdawniejszych swoich wspomnień, a dokładniej próbuje sięgać pamięcią do okresu niemowlęctwa, a nawet czasu przed narodzeniem, by zobrazować myśl o bezczasowości człowieka, jego inercji w czasie, aż do momentu narodzin, a nawet aż do momentu budzenia się świadomości we wczesnym dzieciństwie. Otchłań (бездна) symbolizuje życie człowieka przed na-

\footnotetext{
${ }^{6}$ Wszystkie cytaty z autobiografii Tamte brzegi pochodzą z wydania: В. Набоков, Другие берега, Москва 1989, w nawiasie podany jest numer strony z której pochodzi cytowany fragment.
} 
rodzeniem dziecka - nieświadome, niewiadome i niemożliwe do wyobrażenia dla człowieka oraz życie po śmierci, równie nieświadome i nieznane człowiekowi w doczesności. Bytowanie człowieka w irracjonalności jest zdaniem Nabokova tajemnicą, której on nie jest w stanie zgłębić i zrozumieć, i w swych poszukiwaniach metafizycznego sensu pozostaje zostawiony sam sobie. Nie mając możliwości objąć wieczności rozumem, intuicją, wrażliwością pisarz dochodzi do granicy poznania i stwierdza, że czas jest więzieniem: „Поначалу я не совсем понимал, что безграничное, на первый взгляд, время, есть на самом деле тюрьма.” (21)

Nabokov w swej autobiografii, podobnie jak w całej prozie, wskazuje sposoby na uwolnienie się z więzienia czasu, doświadczenia irracjonalności, a pierwszym z opisanych jest pasja, którą podzielał z ojcem autor - entomologia, kolekcjonowanie i opisywanie motyli. Namiętność ta jest dla Nabokova stałym duchowym łącznikiem z bezczasowością, łowy motyli, podobnie jak twórczość literacka, to autonomia czasowa, przeżycie irracjonalne:

\begin{abstract}
Признаюсь, я не верю во время. Это волшебный ковер я научился так складывать, попользовавшись, чтобы один узор приходился на другой. Пусть спотыкаются посетители. И высшее для меня наслаждение вневременности - это наудачу выбранный пейзаж, где я могу быть в обществе редких бабочек и кормовых их растений. Вот это - блаженство, и за блаженством этим есть нечто, не совсем поддающееся определению. Это вроде какой-то мгновенной физической пустоты, куда устремляется все, что я люблю в мире. Чувство единения с солнцем и скалами. Трепет благодарности, обращенной to whom it may concern - гениальному ли контрапункту человеческой судьбы или благосклонным духам, балующим земного счастливца. $(6,6)^{7}$
\end{abstract}

Doświadczenie wieczności w czasie teraźniejszym to szczególny stan ducha, który w przeświadczeniu pisarza osiągnąć można jedynie poprzez maksymalne skupienie się na przedmiocie swojej namiętności, co z kolei wymaga odosobnienia, samotności. Entomologia oraz literatura potrafią, zdaniem Nabokova, wprowadzić w inne stany świadomości, a poprzez kontakt $\mathrm{z}$ irracjonalnością przyjmują charakter metafizyczny $^{8}$. Z tej racji pasja, żarliwe poświęcenie się jej w celu poszukiwania i doświadczania wieczności może być kojarzona z religijnym zaangażowaniem, które w swym ostatecznym zamierzeniu prowadzi do przekonania o istnieniu nadprzyrodzonej rzeczywistości. Nabokov zdaje się sugerować swym czytelnikom, że pasji oddają się ludzie wybrani, nieprzeciętni, skłonni do największych wyrzeczeń, ale w ostateczności osiągający mądrość nie tylko naukową, przede wszystkim duchową, dającą możność oszukania czasu, panowania nad nim.

Nabokov entomolog wskazał na zjawisko mimikry, czyli ochronne gatunkowe upodobnienia u owadów, które, jak przekonuje, jest irracjonalnym elementem

7 В. Набоков, Память, говори, http://nabokov.niv.ru/nabokov/proza/pamyat-govori/pamyat-govori [dostęp: 15.09.2017]; w kolejnych cytatach w nawiasie podany jest numer rozdziału i podrozdziału, z którego pochodzi cytowany fragment.

${ }^{8}$ Przekonuje o tym również W. Aleksandrow (por. Александров: 1999: 36-38). 
w racjonalnym, logicznym świecie empirycznym. Badanie tego przypadku imitacji, które zdumiewa i wyklucza naukowe wnioski, jest świadectwem pozazmysłowości, którą możemy doświadczyć także w świecie sztuki. Przyroda jest wielką oszustką, mawiał pisarz, nie można więc zaufać jedynie obserwacjom, badaniom i zdrowemu rozsądkowi, należy zawierzyć intuicji niezbędnej każdej sztuce i religii. Pisarz dowodzi zatem rozumowej bezradności człowieka w obliczu irracjonalnego, prowadzącej jednakże do szczęśliwej pewności o jego istnieniu. Dla Nabokova jest to prawda objawiona, epifania, stanowiąca łącznik między tym, co znane, a tym, czego poznać nie można:

\begin{abstract}
Загадка мимикрии всегда пленяла меня. Ее феноменам свойственны художественное совершенство, связываемое обычно лишь с творениями человека.(...) "Естественный подбор" в дарвиновском смысле не может служить объяснением чудотворного совпадения подражания внешнего и подражательного поведения; с другой же стороны, и к “борьбе за существование" аппелировать невозможно, когда защитная уловка доводится до такой точки миметической изощренности, изобильности и роскоши, которая находится далеко за пределами того, что способен оценить мозг врага. Я нашел в природе те “бесполезные" упоения, которых искал в искусстве. И та и другое суть формы магии, и та и другое - игры, полные замысловатого волхвования и лукавства. $(6,2)$
\end{abstract}

Zdolność jasnowidzenia to kolejny z opisywanych przez Nabokova irracjonalnych talentów, darów dzieciństwa. B. Awierin przekonuje, iż na podobieństwo twórców symbolistów poznanie świata dla pisarza wynika z indywidualnego przeżycia, które opiera się na snach, proroczej intuicji i wizjonerstwie (Аверин 2003: 249-252). Nabokov w powieści Dar oraz w autobiografii wspomina dziecięcy okres choroby, kiedy zmuszony do domowej rekonwalescencji nagradzany był przez matkę różnymi upominkami, z niecierpliwością przez niego wyczekiwanymi. Jeden z prezentów - ozdobny, dużych rozmiarów ołówek, pisarz ujrzał we własnej wyobraźni, a kiedy go wkrótce otrzymał, stanowił świadectwo niezwykłych imaginacyjnych, proroczych możliwości małego Vladimira. Nabokov podkreślił tym samym własny duchowy elitaryzm, sytuując siebie wśród niezwyczajnych wybitnych ludzi, predestynowanych do wyjątkowej działalności, przeznaczonych do korzystania z talentu, którym zostali hojnie obdarowani. Umiejętność przewidywania przyszłości, przedsennych halucynacji dowodzi również niezwykłości okresu dzieciństwa, rozumianego jako czasu formowania się świadomości, bliskości z irracjonalnością, którą w miarę dorastania wypiera rozum, zdrowy rozsądek. Pisarz sugeruje, że tylko jednostki wybitne mogą zachować nieskażoną wyobraźnię, czystą wrażliwość i ufną intuicję, czyli cechy charakterystyczne dla wieku dziecięcego. Wybitny twórca, zdaniem Nabokova, nie wyzbywa się tych dziecięcych umiejętności, a przywoływanie dziecięctwa, wspominanie o nim, jest czerpaniem z utraconych doświadczeń i przeżyć wielokrotnie i co cenniejsze, umiejętnym spożytkowaniem owych predylekcji w dorosłości, racjonalnie.

Kolejnym z zaprezentowanych przez autora, najważniejszym z nabokovowskich talentów jest pasja twórcza. Pisarz dokładnie datuje w swej autobiografii lato 
1914 r., które ujawniło pisarski potencjał Nabokova, drobiazgowo wspomina swój pierwszy wiersz, wszystkie doznania, jakie towarzyszyły temu doniosłemu aktowi. Przypominane wcześniej umiejętności i zdolności przygotowywały czytelnika do opisu najważniejszego daru, talentu twórczego, początkowo objawiającego się poetycką inwencją, a później prozatorską finezją, autor drobiazgowo wspomina:

Следующий миг стал началом моего первого стихотворения. Что подтолкнуло его? Кажется, знаю. Без единого дуновения ветерка, один только вес дождевой капли, сияющей в паразитической роскоши на душистом сердцевидном листке, заставляет его кончик кануть вниз, и подобие ртутной капли внезапно соскальзывает по его срединной прожилке, и лист, обронив яркий груз, взлетает вверх. Лист, душист, благоухает, роняет - мгновение, за которое все это случилось, кажется мне не столько отрезком, сколько разрывом времени, недостающим ударом сердца, сразу вернувшимся в перестуке ритма: говорю “в перестуке", потому что когда и впрямь налетел ветер, деревья принялись все разом бодро стряхивать капли, настолько же приблизительно подражая недавнему ливню, насколько строфа, которую я уже проборматывал, походила на потрясенье от чуда, испытанное мною в миг, когда сердце и лист были одно. $(11,1)$

Akt twórczy nazywa Nabokov „szczeliną” w czasie teraźniejszym, cudem, który oznacza zawsze tylko jedno - kontakt z wiecznością, irracjonalnością. Opuszczanie czasu racjonalnego i doświadczanie czasu wiecznego, towarzyszy zresztą wszystkim momentom tworzenia, kiedy autor pisze o „wchodzeniu w trans" (,я впал в наиболее гипнотическое из череды этих состояний”), a więc o całkowitym oderwaniu od rzeczywistości, o natchnieniu, które zabiera go w inny wymiar istnienia, oferuje odmienne stany świadomości. Pisarz, aby wytłumaczyć ten proces posługuje się opinią znanej filozofki Vivian Bloodmark (kolejnej wymyślonej postaci, a anagram nazwiska autora wskazuje, że są to poglądy samego Nabokova) ${ }^{9}$, iż uczony widzi wszystko, co się zdarza, w jednym punkcie przestrzeni, natomiast poeta odczuwa i przeżywa wszystko, co się zdarza w jednym punkcie czasu. Zdolność tę, przynależną genialnym twórcom, pisarz nazywa „kosmiczną synchronizacją” („космическая синхронизация”) $(11,2)$, czyli postrzeganiem i rozumieniem wielu rzeczy jednocześnie, kosmiczna synchronizacja jest boskim przymiotem dostępnym jedynie dla wybranych. Dla Nabokova jest to najdonioślejsze przeżycie czasowej autonomii, pozazmysłowej wolności, cudownej ucieczki od realnego świata i nieuchronności następstwa czasu.

Autor stwierdza, że czas jest ograniczony przez świadomość, a należałoby przyjąć, że to świadomość jest wyróżnikiem czasu ${ }^{10}$. Dla Nabokova takim granicznym świadomym momentem czasowym jego życia był wiek czterech lat,

9 W. Aleksandrow nazywa podobne zagadki Nabokova estetyką oszustwa (,„стетика обмана”), stanowiącą naczelną normę estetyczną, kryjącą zamaskowane kluczowe zagadnienia dla pisarza (por. Александров 1999: 33).

${ }^{10}$ O korelacji pomiędzy świadomością i czasowością życia bohaterów Nabokova pisze K. A. Barszt, który podkreśla znaczenie pamięci ontologicznej (por. Баршт 2008: 48-57). 
kiedy jego pamięć wyławia z bezczasowości obraz spaceru z rodzicami. Autor wydarzenie to przedstawia jako fragmentaryczne przebłyski świadomości, które z czasem pozwoliły mu na postrzeganie i rozumienie czasu jako chronologicznego ciągu następujących po sobie wydarzeń. Dla samoświadomości był to moment narodzin, powtórnych narodzin, które określały tym razem rozumowy ogląd świata. Dzieciństwo Nabokov opisuje jako beztroski, idylliczny czas letnich wakacji w wiejskich rodzinnych majątkach Wyra i Batowo, ekscytujących podróży na południe Europy i spokojnych zimowych miesięcy w petersburskim domu. B. Awierin wspomnieniowy powrót Nabokova do okresu dzieciństwa uzasadnia kulturowym toposem literatury rosyjskiej początku XX w., z którym wiąże się metafizyczna interpretacja tematu ,utraconego raju dzieciństwa”. Badacz uważa, że opuszczenie dziecięcego raju wynikało $\mathrm{w}$ przypadku pisarza nie tylko $\mathrm{z}$ nieuchronnego procesu dorastania, bowiem oznaczało dla Nabokova realne wygnanie, przymusowe porzucenie domu dzieciństwa i ojczyzny. Awierin przekonuje, że był to „błogosławiony” czynnik formujący literacką sylwetkę pisarza, a nie jego dramat (por. Аверин 2003: 234-238), bowiem warunkował wspomnienia i niejako zmusił Nabokova do budowania własnej, niezależnej pozycji w literaturze. Wiktor Jerofiejew natomiast nieświadomy okres niemowlęcy w życiu człowieka traktuje jako czas maksymalnego przybliżenia się do irracjonalności, który wraz z wczesnym dzieciństwem jest także okresem czystej, błogosławionej i zagadkowej akceptacji świata. Badacz twórczości Nabokova, jego „utraconego raju dzieciństwa" nazywa go idyllicznym czasem, z którego wygnanie jest procesem nieuchronnym, podobnie nieutulonej tęsknocie za nim ${ }^{11}$. Szczęśliwe dzieciństwo pisarza, $\mathrm{z}$ jednej strony wyidealizowane przez autora, $\mathrm{z}$ drugiej natomiast opisane z drobiazgową wiernością, stanowi sedno jego autobiograficznych wspomnien, na nim Nabokov skupia większość swej uwagi, do której wprowadza nielicznych przodków, rodzeństwo, a przede wszystkim rodziców.

Szczególne miejsce w dziecięcych wspomnieniach pisarza zajmuje jego matka Elena, przedstawiona jako osoba najbliższa, najlepiej rozumiejąca i mająca największy wpływ na ukształtowanie jego osobowości poprzez bezgraniczną miłość, całkowitą akceptację i dozgonną wiarę w wyjątkowość syna. W relacji Nabokova matka była najlepszą nauczycielką jego wrażliwości i talentu, ona uczyła go zapamiętywać świat, ona słuchała jego pierwszych wierszy, pokazała mu niezależność i wielką siłę charakteru. Wyidealizowana, emocjonalnie opisana postać matki jest nieodłącznym elementem, duchową patronką szczęśliwego dzieciństwa pisarza:

“О, еще бы”, говаривала мать, когда бывало я упоминал то или другое необычайное ощущение, “еще бы, это я хорошо знаю”. (...) Ее проникновенная и невинная вера одинаково принимала и существование иного мира, и невозможность осмыслить его в понятиях земной жизни. (...) Любить всей душой, а в остальном доверяться судьбе

${ }^{11}$ W. Erofiejew interpretuje twórczość Nabokova w kategoriach raju utraconego - потерянного рая; por. Ерофеев 1989: 5-17). 
- таково было ее простое правило. “Вот запомни”, -говорила она заговорщицким голосом, предлагая моему вниманию заветную подробность Выры (...) Как будто предчувствуя, что вещественная часть ее мира должна скоро погибнуть, она необыкновенно бережно относилась ко всем вешкам времени, рассыпанным по нашему сельскому поместью. Прошлое свое она лелеяла с таким же ретроспективным пылом, с каким я теперь лелею мое. Так что я, по-своему, унаследовал восхитительные подобия, все красоты неотторжимых богатств, призрачное имущество - и это оказалось прекрасным закалом от предназначенных потерь. (30-31)

Bez wątpienia z matką Vladimir odnajdował wyraźną mentalną bliskość, za jej życia świetnie się rozumieli, bawili, lubili przebywać w swoim towarzystwie, a pewnego rodzaju porozumienia duchowego nawet po jej śmierci możemy doszukiwać się w dygresji, jaką zamieścił Nabokov o sennych wizytach nieżyjących najbliższych, świadczącej o tym, że łączność duchowa pomiędzy żywymi i zmarłymi istnieje, może w nieco innej formie niż za ich życia, ale nieprzerwanie:

Когда мне снятся умершие, они всегда молчаливы, озабочены, смутно подавлены чем-то, совсем не похожи на себя, дорогих, ярких. Я встречаюсь с ними без удивления, в обстановке, в которой они никогда не бывали при жизни, - например, в доме у кого-то, с кем я подружился потом. Они сидят в сторонке, хмуро опустив глаза, как если бы смерть была темным пятном, постыдной семейной тайной. (36)

Ojciec Nabokova - Wladimir Nabokow, liberalny działacz polityczny, posiada nie mniej wdzięczny wizerunek w synowskiej autobiografii. Autor opisuje wspólne łowy motyli, rowerowe wycieczki, polityczne obowiązki oraz sportową dyscyplinę ojca, kreśląc portret człowieka zaangażowanego w przemiany w Rosji i jednocześnie oddanego rodzinie. Portret ojca nie jest tak szczegółowy jak matki, jego postać pojawia się w trakcie opisów różnych zdarzeń, natomiast uzupełniany wielokrotnie tworzy spójne wyobrażenie o inspirującej roli, jaką odegrał w życiu Nabokova ${ }^{12}$.

(...) нежная дружба, на которой зиждилось мое уважение к отцу; обаяние полноты нашего совершенного согласия; уимблдонские матчи, за которыми мы следили по лондонским газетам; шахматные задачи, которые мы вместе решали; пушкинские ямбы, триумфально слетавшие с его языка всякий раз, что я упоминал кого-нибудь из мелких современных поэтов. Наши отношения окрашивал повседневный обмен домодельными нелепицами, комично искаженными словечками, имитациями традиционных интонаций, всеми теми скрытыми от других семейными шутками, которые составляют тайный шифр счастливых семей. Он был до крайности строг в вопросах поведения и склонен к резкостям, $(\ldots)(9,5)$

${ }^{12}$ A. Mularczyk uważa, że ojciec Nabokova w jego autobiografii pozostaje jakby „poza kadrem”, mało autor o nim pisze, natomiast wyczuwa się stałą obecność Władimira Nabokowa (por. Мулярчик: 1997: 117). 
Autobiografia Nabokova utrwala czas przeszły, ukazuje życie Vladimira Nabokova i jego rodziny w perspektywie kilkudziesięciu lat, szczęśliwego beztroskiego dzieciństwa, burzliwego dorastania i trudnej emigracyjnej dorosłości autora. Pisarz opisuje również codzienne życie rodziny Nabokovów, stałe domowe rytuały, rozrywki i obowiązki, wylicza kolejne guwernantki, całą rzeszę domowych nauczycieli, wspomina pierwszą szkołę, pierwszą miłość, wymuszoną emigrację, studia w Anglii, wreszcie pobyt w Niemczech i Francji. Obraz jego dzieciństwa i wczesnej młodości składa się na wizerunek życia człowieka zwyczajnego i jednocześnie wyjątkowego, można mieć wrażenie, że Nabokov we własnym życiorysie poszukuje wraz z czytelnikami prawidłowości, znamion przyszłości, wzoru, jak sam określa, indywidualnego losu. Wzorzec ów powinien wykazać ścisłą współzależność przeszłości i współczesności, zawierać zapowiedź przyszłych wydarzeń, a co za tym idzie, przekonać, że los każdego człowieka, w tym przypadku Nabokova, był z góry określony.

Koncepcja czasu indywidualnego przedstawionego przez Nabokova w formie spirali, która zamienia się w koło świadczy o przekonaniu, iż czas każdego człowieka wpisuje się w nieskończoną formę bytu i jednocześnie, że jest zamknięty, ograniczony, toczy się wśród określonych, wyznaczonych parametrów. Autobiografia pozwala na uświadomienie i zrozumienie współzależności ludzi i wydarzeń, których życiowy splot układa się w spójną formę. Śledząc losy Nabokova dochodzimy, za jego sugestią, do wniosku o istnieniu wyższej logiki człowieczych doświadczeń, które niezrozumiałe w danym momencie życia przemawiają w swojej oczywistości z perspektywy czasu. Autobiografia, w przeświadczeniu Nabokova, wyjawia indywidualny, niepowtarzalny wzorzec („узор”) nieświadomie przeżytych wydarzeń, układających się w rysunek życia, przeznaczenia, o czym pisze także B. Awierin: „Вообще же «тайные знаки», которые превращают жизненный «ландшафт» в «сложный код» - вечная тема Набокова" (Аверин 2003: 292).

Autobiografia Nabokova jest więc dojrzałą, zhierarchizowaną wizją życiorysu dziecka, młodego utalentowanego człowieka konsekwentnie podążającego za swoimi nierzadko trudnymi wyborami, godzącego się na kolejne obroty koła - spirali czasu.

Спираль - одухотворение круга. В ней, разомкнувшись и раскрывшись, круг перестает быть порочным, он получает свободу. (...) Завои следуют один за другим, и каждый синтез представляет тезис следующей серии. Возьмем простейшую спираль, в которой можно различить три элемента, или загиба, отвечающие элементам триады: назовем “тезисом” первую дугу, с которой спираль начинается в некоем центре; “антитезисом” - дугу покрупнее, которая противополагается первой, продолжая ее; а “синтезом” дугу еще более крупную, которая продолжает вторую, заворачиваясь вдоль наружной стороны первого загиба. И так далее. Цветная спираль в стеклянном шарике - вот какой я вижу мою жизнь. $(14,1)$ 
Początek i koniec autobiografii to opis dzieciństwa, zaczyna się od Vladimira Nabokova i kończy opisem dzieciństwa syna autora pokazanego z rodzicielskiej perspektywy. Wspomniana nieskończona, kolista forma czasu domyka się więc idealnie, ale nie jest obowiązująca, ponieważ pisarz wielokrotnie wskazywał sposoby opuszczenia czasowej spirali, momenty duchowej wieczności, która stanowi najważniejsze dla pisarza życiowe doświadczenie. Metafizyka pamięci ukazuje pozazmysłową głębię życiorysu Nabokova, podkreśla duchowy aspekt wszystkich jego talentów, irracjonalną perspektywę jego niezwykłej biografii.

\section{Bibliografia}

Аверин Б. (2003), Дар Мнемозины. Романы Набокова в контекстерусскойавтобиографической традииии, Санкт-Петербург.

Александров В. Е. (1999), Набоков и потусторонность: метафизика, этика, эстетика, Санкт-Петербург.

Баршт К. А. (2008), Мнемозина Владимира Набокова. Правда онтологической памяти, [в:] Литература русского зарубежью (1920-1940-е годы). Взгляд из ХХІ века. Материаль Международной научно-практической конференции 4-6 октября 2007 года, под ред. Л. А. Иезуловой, С. Д. Титаренко, Санкт-Петербург, s. 48-57.

Демидова О. П. (2010), Мемуары как пространство экзистенции, [в:] Мемуары в культуре русского зарубежья. Сборник статей, Санкт-Петербург.

Ерофеев В. (1989), Набоков в поисках потерянного рая, [в:] В. Набоков, Другие берега, Москва, s. 5-17.

Мулярчик А. С. (1997), Русская проза Владимира Набокова, Москва.

Набоков В. (1989), Другие берега, Москва.

Набоков В., Память, говори, http://nabokov.niv.ru/nabokov/proza/pamyat-govori/pamyat-govori [dostęp: 15.09.2017].

Федотов Ф. О. (2010), Мемуары как проблема, [в:] Мемуары в культуре русского зарубежья, ред. А. Данилевский, Москва.

Czermińska M. (1987), Autobiografia i powieść czyli pisarz i jego postacie, Gdańsk.

Czermińska M. (red.) (2009), Autobiografia, Gdańsk.

Engelking L. (2011), Chwyt metafizyczny. Vladimir Nabokov - estetyka z sankcją wyższej rzeczywistości, Łódź.

Fabianowski A. (2001), „Powieść nie skończona...” Pułapki romantycznego autobiografizmu, [w:] Autobiografizm - przemiany, formy, znaczenia, red. H. Gosk, A. Zieniewicz, Warszawa.

Gusdorf G. (2009), Warunki i ograniczenia autobiografii, thum. J. Barczyński, [w:] Autobiografia, red. M. Czermińska, Gdańsk.

Kasperski E. (2001), Autobiografia. Sytuacja i wyznaczniki formy, [w:] Autobiografizm-przemiany, formy, znaczenia, red. H. Gosk, A. Zieniewicz, Warszawa, s. 10-14.

Lubas-Bartoszyńska R. (1993), Między autobiografia a literatura, Warszawa.

Ricoeur P. (1992), Filozofia osoby, przeł. M. Frankiewicz, Kraków.

Yates F. A. (1977), Sztuka pamięci, przeł. W. Radwański, Wstęp, L. Szczucki, Warszawa. 


\section{METAPHYSICS OF MEMORY IN AUTOBIOGRAPHICAL TEXTS BY VLADIMIR NABOKOV}

(Summary)

The article is divoted to the specificity of Nabokov's autobiographical writings. As it is shown, their characteristic features are determined by biographical conceptualism, which makes it possibile for the writer to explain philosophy of his own perception and to evaluate the reality. In this way Nabokov also presented the key categories of his life's and author's hierarchy. What is worth mentioning, in his autobiographical texts Nabokov concentrated on emphasizing individual and subjective aspects that had influenced his author's consciousness.

Keywords: Vladimir Nabokov, autobiography, memory, conceptualisation of time

\section{METAFIZYKA PAMIECI WE WSPOMNIENIOWEJ PROZIE VLADIMIRA NABOKOVA}

(Streszczenie)

Artykuł poświęcony jest specyfice nabokovowskiego autobiografizmu. Jak to zostało przedstawione, jego cechy charakterystyczne uwarunkowane są biograficzną konceptualizacją, poprzez którą pisarz starał się wyjaśnić filozofię własnego postrzegania i ocenę rzeczywistości. W ten sposób Nabokov zaprezentował też kategorie kluczowe w jego życiowej i pisarskiej hierarchii. Co istotne, w autobiografiach Nabokov koncentrował się na tym, co służyło podkreśleniu przede wszystkim indywidualizm i subiektywizm w formowaniu jego światopoglądu pisarskiego.

Słowa kluczowe: Vladimir Nabokov, autobiografia, pamięć, konceptualizacja czasu 